\title{
Rideriana amazonica gen. nov. and sp. nov. of Pentatomini (Heteroptera, Pentatomidae) ${ }^{1}$
}

\author{
Jocélia Grazia ${ }^{2} \&$ Angélica Frey-da-Silva ${ }^{2}$
}

${ }^{1}$ Contribution number 395 of the Departamento de Zoologia, Universidade Federal do Rio Grande do Sul.

${ }^{2}$ Universidade Federal do Rio Grande do Sul, Instituto de Biociências, Departamento de Zoologia, Prédio 43435. Av. Bento

Gonçalves 9500, 91501-970. Porto Alegre, RS, Brasil. Bolsista CNPq. E-mail: jocelia@ufrgs.br; angelzi@zipmail.com.br

\begin{abstract}
A new Neotropical genus Rideriana gen. nov. is proposed to include R. amazonica sp. nov., from Cuzco (Peru), Acre (Brazil) and La Paz (Bolivia).
\end{abstract}

KEY WORDS. Hemiptera, Neotropical, taxonomy.

During the study of the genera Similiserdia Fortes \& Grazia, 1998 and Serdia Stål, 1860 a male specimen from the Amazonian region with similar facies to the species of these genera, but not belonging to no one of them was studied. Recently, Dr. David Rider sent two more specimens from the Amazonian region of Peru and Bolivia which alowed the authors to describe this new genus and new species.

The new genus belongs to section 3 of Rolston et al. (1980), which is characterized by the presence of a median tubercle on third urosternite apposed by the posterior margin of metasternum.

\section{MATERIAL AND METHODS}

The specimens studied belong to the following collections: Entomological Collection, Department of Entomology, National Museum of Natural History, Washington, District of Columbia, USA (USNM); Instituto Nacional de Pesquisas da Amazônia, Manaus, Amazonas, Brazil (INPA).

Measurements are given in millimetres. The terminology of Dupuis (1970) and Grazia et al. (1999) was adopted for the structure of the genitalia.

\section{Rideriana gen. nov.}

Type species: Rideriana amazonica Grazia \& Frey-da-Silva, here described.

Dorsal surface of body intense and uniformly punctured; ventral surface of the thorax with more sparse and bigger punctures. Head wider than long. Juga longer than and confluent before tylus; lateral margins of juga slightly emarginate; dorsal surface with transverse furrows. Antennal tubercles with rhomboid lateral spine. Antennal segment I surpassing apex of head, densely punctured; segment II extremely reduced. Relative length of antennal segments: $\mathrm{V}>\mathrm{III} \approx \mathrm{IV}>\mathrm{I}>\mathrm{II}$. Bucculae subrectilinear, evanescent at base of head with well developed anterior tooth. Rostrum short, attaining mesosternum. Rostral segment I shorter than bucculae; segments II and III subequal in length, longer than I and IV.

Pronotum subtrapezoidal, anterior $2 / 3$ strongly declivent. Anterolateral margins subrectilinear, scarcely deflected and with angles distinctly toothed; posterolateral margins sinuous. Humeral angles not developed, rounded. Posterior margin subrectilinear. Dorsal surface with scattered yellowish maculae; $1+1$ maculae at lateral angles of cicatrices. Prosternum flat between crests limiting this area; mesosternum carinate, anteriorly acute and projected between procoxae; metasternum elevate, anteriorly acute and projected between mesocoxae, posteriorly bifurcate. Ostiolar rugae short, clavate, length 1/4 of evaporatory areas width. Evaporatory areas infuscate, slightly rugose near ostiolum, covering 3/4 of metapleura and almost apical half of mesopleura.

Scutellum longer than wide at base; basal angles foveate, apex slightly acute reaching connexival segment VI at middle. Posterior angle of corium subacute, reaching posterior margin of connexival segment VI; posterior margin of corium subrectilinear. Apex of vein Radius with small pale yellow callus followed by dark-castaneous macula. Hemelytra surface with scattered yellowish maculae; membrane infuscate. Femur toothed at limits of apical fourth; tibia dorsally sulcate. Femur and tibia with dark castaneous punctures; tarsi immaculate.

Connexivum scarcely exposed. Postero-lateral angles in black tine spines. Abdominal spine extending between metacoxae, apposed to posterior margin of metasternum. Spiracles sided entad by yellowish callus. Trichobothria placed laterad to the imaginary longitudinal line tangential to the spiracles. Abdominal median third, sutures and pseudo-sutures with black maculae; disc with scattered punctures. 


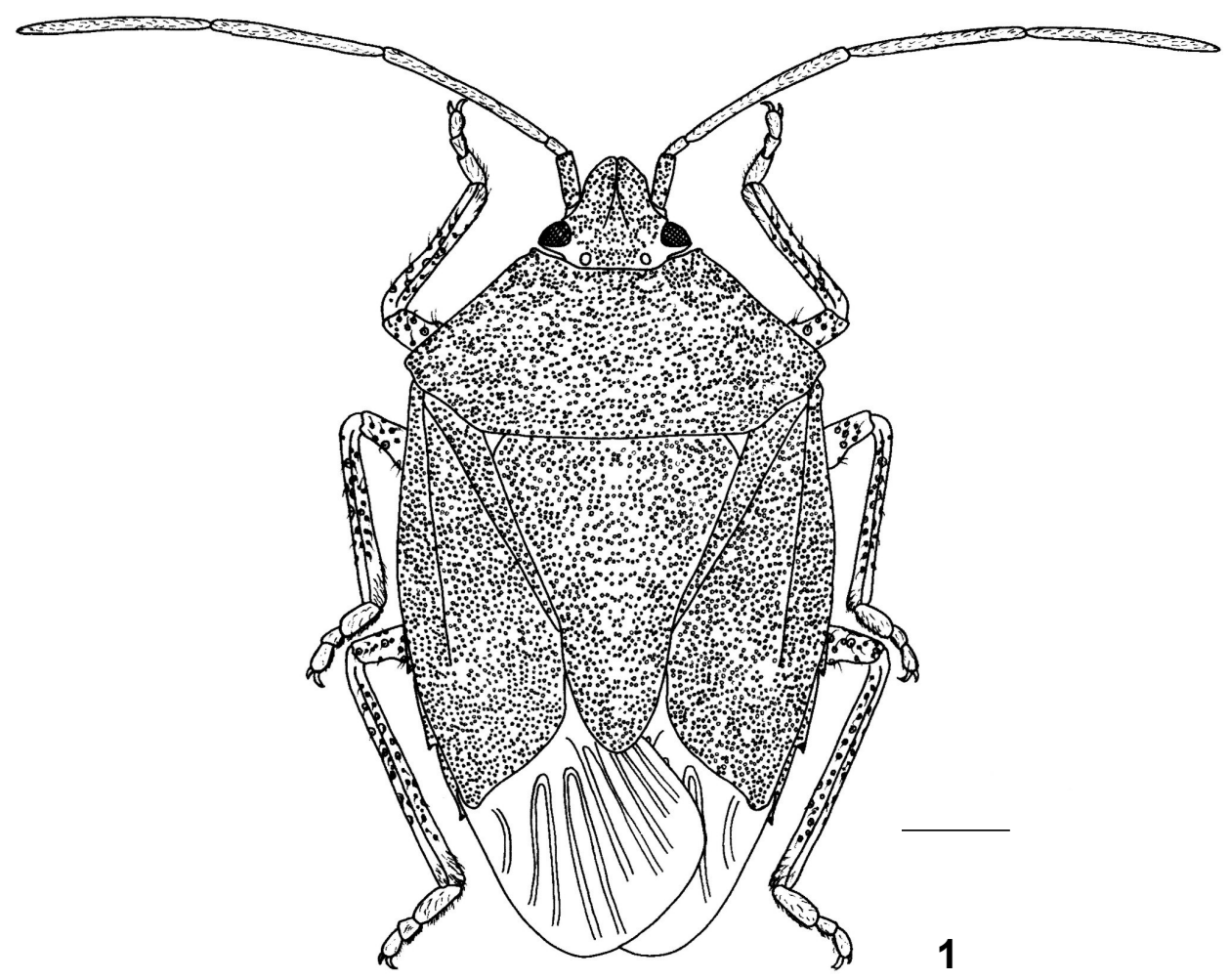

Figure 1. Habitus. Rideriana amazonica sp. nov., holotype. Scale: $1 \mathrm{~mm}$.

Male. Pygophore quadrangular, posterolateral angles produced posteriorly; dorsal rim (dr) shallowly escavate; ventral rim (vr) escavate with strongly developed hypandrium. Segment X (proctiger) pyriform in dorsal view, apex ventrally directed. Parameres (pa) well developed.

Phallus. Basal plate (bp) well developed longer than phallotheca ( $\mathrm{ph})$. Phallotheca opened postero-ventrally; postero-lateral angles produced. Processus capitati (pc) wide, almost twice the length of dorsal connective (dc). Vesica (v) well developed, almost twice the length of phallotheca, with processes ventrally projected. Conjunctiva absent. Ductus seminis distalis (dsd) long, twice the length of phallotheca, slightly wider at basal half.

Comments. Rideriana gen. nov. has the "facies" of three known genera belonging to Section 3 of Rolston et al. (1980): Serdia, Elsiella Froeschner, 1981, and Similiserdia. It can be separated from these genera by the extremely reduced second antennal segment, and, at least from Similiserdia and Serdia, by the presence of well-developed hypandrium on ventral rim of pygophore (Elsiella is known only from females). In Serdia and one of the species of Similiserdia (S. aciculata) the antennal segment II is almost equal in length with segment I, and never surpassing $1 / 3$ of III; in Rideriana gen. nov. the antennal segment II corresponds to $1 / 3$ of antennal segment I and almost $1 / 9$ of segment III. Also Rideriana gen. nov. can be distinguished from Similiserdia by the presence of mesosternal carina, and jugae with lateral margins slightly deflected. In Similiserdia the mesosternum is sulcate and the lateral margins of jugae are not deflected. From Serdia and Elsiella, the new genus can be separated by the antennal segment I surpassing apex of head; both genera have antennal segment I not, or at least, reaching apex of head. Finally, Rideriana gen. nov. has short rostrum, attaining mesosternum, a character shared with Similiserdia and Serdia; in Elsiella the rostrum just surpasses the anterior margin of third abdominal sternite.

Etymology. The genus is named in honour to Dr. David Rider for his continued effort in cataloguing the pentatomids.

\section{Rideriana amazonica sp. nov. Figs $1-8$}

Male (Fig. 1). Body length 15.42 (15.20-15.70); head length 2.37 (2.32-2.48), head width 3.09 (3.04-3.12); length before eyes 1.46 (1.44-1.52); width between eyes 1.81 (1.76$1.84)$; pronotal length 3.57 (3.44-3.68), pronotal width 8.56 (8.40-8.80); scutellar length 6.68 (6.64-6.72), scutellar width 5.44 ; corium length 8.93 (8.48-9.20); length of antennal segments: I 1.20 (1.12-1.28); II 0.42 (0.40-0.48); III 3.76 (3.683.84); IV 3.84; V 4.04 (3.92-4.16).

Dorsal surface of body castaneous to yellowish-castaneous, densely punctured; punctures dark-castaneous. Ventral surface yellowish with scattered ferrugineous to black punctures, bigger than dorsal punctures of thorax. Lateral margins of jugae finely black bordered. Antennal segments II, III and IV reddish-castaneous; segment I mate, densely punctured; segment $\mathrm{V}$ yellowish, punctures faded. 


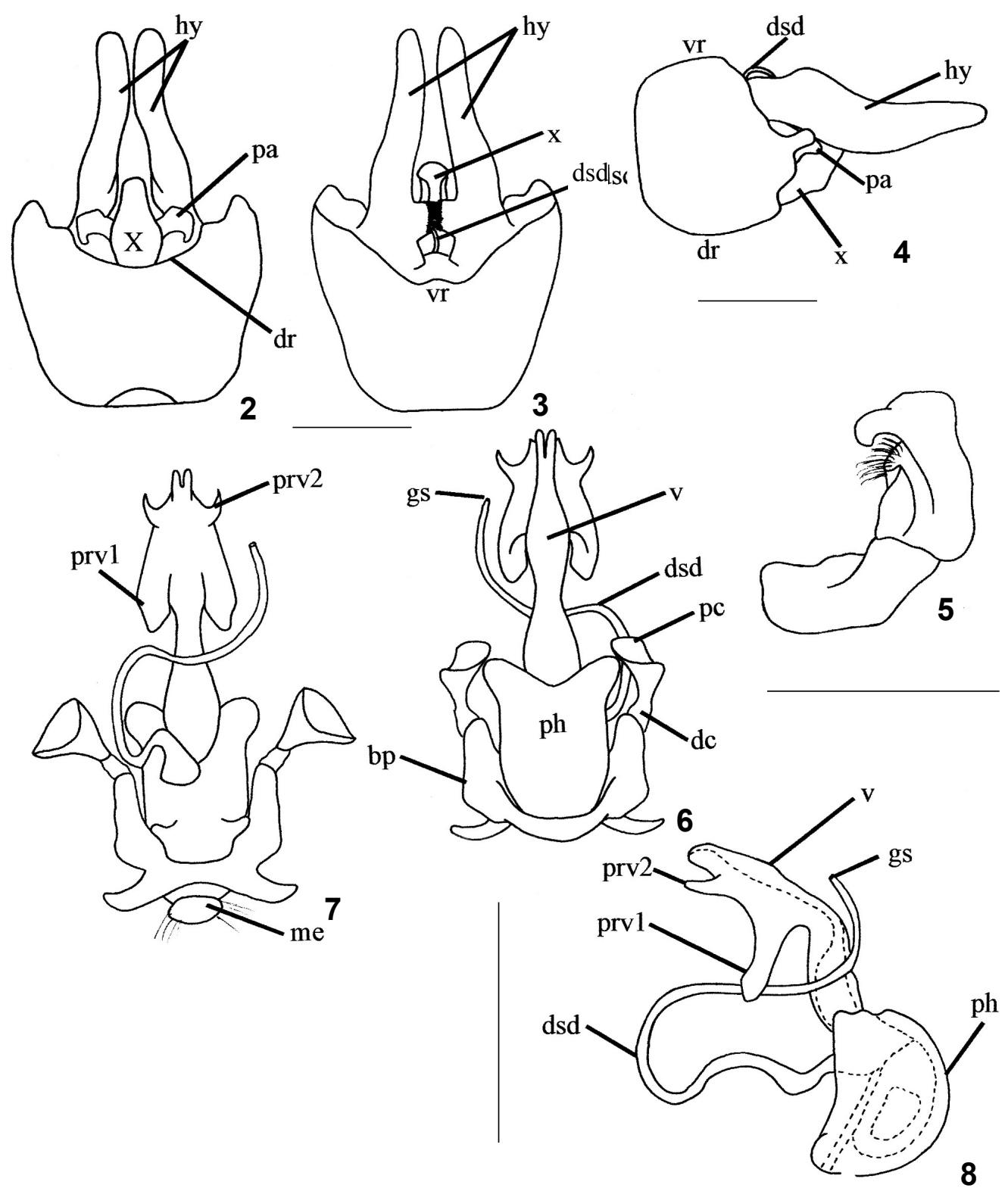

Figures 2-8. Rideriana amazonica sp. nov. (2-5) Pygophore: (2) dorsal, (3) ventral and (4) lateral view respectively, (5) right paramere: lateral view; (6-8) Phallus: (6) dorsal, (7) ventral and (8) lateral view respectively. (bp) basal plate, (dc) dorsal connectives, (dr) dorsal rim, (dsd) ductus seminis distalis, (gs) secundary gonopore, (hy) hypandrium, (me) membramblase, (pa) paramere, (pc) processus capitati, (ph) phallotheca, (prv1) processus vesicae 1, (prv2) processus vesicae 2, (vr) ventral rim, (v) vesica, (x) tenth segment. Scale: $1 \mathrm{~mm}$.

Pronotum cicatrices inconspicuous. Mesosternal carina yellowish; metasternal carina reddish, black punctured. Evaporatory areas yellowish. Legs mate, with castaneous maculae; tarsi reddish, immaculate. Spiracles black sided entad by yellowish callus.

Genitalia. Hypandrium (hy) strongly developed, longer than the pygophore, along mid line bifurcated, each ramus laterally flat, apex digitiform (Figs 2-4). Parameres geniculate, apex turned to the bottom of genital cup (Fig. 5). Phallus. Vesica well-developed; apical half turned ventrad, with a pair of processes, one basal - processus vesicae 1 (prv1) more sclerotized, longer, ventrally directed, and one apical - processus vesicae 2 (prv2) membranous, shorter, posteroventrally directed. Ductus seminis distalis very long, almost twice the length of vesica, emerging from its base, projecting ventrad and folding dorsad, the apical fifth directed posteriorly (Figs 6-8).

Revista Brasileira de Zoologia 20 (3): 507-510, setembro 2003 
Female unknown.

Type material. Holotype male: Peru, Cuzco: Prov. Paucartambo, Hacienda Maria, Shores of River Cosnipata, 15.III.1952, F. Woytkowski leg., J.C. Lutz Collection 1961 (USNM). Paratypes: BrazIL, Acre: $11 \mathrm{Km} \mathrm{Ne}$ do Rio Branco, 06.V.1981, Jorge Arias leg., 1 male (INPA). Bolivia, La Paz: Mapiri (N. La Paz), 10-16.VIII.1989, L.E. Peña leg., Coll. Drake, 1 male (USNM).

\section{ACKNOWLEDGEMENTS}

To Dr. Thomas Henry (USNM), Dr. David Rider, North Dakota State University, USA, and Dr. José Albertino Rafael (INPA) for the loan of the specimens.

Received in 17.III.2003; accepted in 25.VIII.2003.

\section{REFERENCES}

Dupuis, C. 1970. Heteroptera, p. 190-208. In: S.L. Tuxen (Ed.) Taxonomist's glossary of insects. Copenhagen, Munksgaard, 359p.

Grazia, J.; J.A.M. Fernandes \& C.F. Schwertner. 1999. Stysiana, a new genus and four new species of Pentatomini (Heteroptera, Pentatomidae) of the Neotropical region. Acta Societatis Zoologicae Bohemicae, Praga, 63 (1-2): 71-83.

Rolston, L.H.; F.J.D. McDonald \& D.B. Thomas JR. 1980. A conspectus of Pentatomini genera of the Western Hemisphere. Part I (Hemiptera: Pentatomidae). Journal of the New York Entomological Society, New York, 88 (2): 120-132.

Revista Brasileira de Zoologia 20 (3): 507-510, setembro 2003 